\title{
National systems of technology transfer of BRICS countries: features of formation
}

\author{
Yuliana Solovieva ${ }^{1, *}$, and Mingjun $\mathrm{He}^{2}$, \\ ${ }^{1}$ Peoples' Friendship University of Russia (RUDN University), Miklukho-Maklaya Street, 6, 117198 \\ Moscow, Russia \\ ${ }^{2}$ Kunming Polytechnic University, Qingming nanlu str., 727, Chengdong district, Kunming, China
}

\begin{abstract}
The article considers the features of creation and development of organizational systems of technology transfer in the BRICS member countries (Brazil, Russian Federation, India, China, South Africa), interaction of participants in the innovation process. The author identifies the significant role of the regional component in the formation of effective national innovation systems. The purpose of the article is to analyze the national innovation systems of the BRICS member countries, since each of these countries has gone its own way of innovative development, justified by regional characteristics. Based on the analysis of transfer systems operating in the BRICS countries, the author identifies key and most promising areas for the development of the integration of the scientific and educational, production spheres and the state in order to form special mechanisms for organizing innovative processes that ensure effective interaction between all its participants, contributing to the formation of competitive high-tech products.
\end{abstract}

\section{Introduction}

The economic development of any state depends on many of socio-economic, political and other factors that affect not only the increase in real production, but also economic growth, in general, its improvement in quality. As economies develop, these factors change, assess and reassess their importance. For most of the technology leaders, the development of the innovation sphere, the knowledge economy, and technological transfer are becoming priority areas. In the context of modern socio-economic transformations, it is the level of development of the national innovation system that creates the world economic superiority of the country.

Technology transfer is one of the main factors in the development of both national economies and the global economy as a whole. The degree of participation of each country in the process of obtaining and implementing the results of intellectual activity largely determines both the prospects for the country's scientific and technological development and its competitiveness. In modern conditions, it is the level of innovation and technological development, based on the production and transfer of high-tech products, that contributes to the world economic superiority of the country.

*Corresponding author: jouliana_sol@mail.ru 
Economic organizations, unions, various integration groups occupy a special place in the world market of high technologies. So, the BRICS member countries have considerable potential based on an effectively developing economy and a large resource base of world importance: «Brazil - the 7th economy of the world at par of GDP, is rich with agricultural production, is close to position of great powers; Russia - the 5th-6th economy of the world in terms of GDP parity, rich in mineral resources, has the largest territory in the world, one of the two largest nuclear powers in the world; India - the 3rd economy of the world at par GDP, cheap intellectual resources, one of two countries with more than milliard population, the nuclear power, is close to position of great powers; China - the 1st economy of the world in terms of GDP parity and the 1st exporter in the world ("world factory"), the owner of the world's largest foreign exchange reserves, has the world's largest population, a nuclear power; The Republic of South Africa - the 25-29th economy of the world at par GDP, various natural resources, the main African regional power» [10].

The purpose of the article is to analyze the national innovation systems of the BRICS member countries, since each of these countries has gone its own way of innovative development, justified by regional characteristics (climatic, cultural, socio-economic, etc.).

\section{Methodology}

As basic research methods we used system approach, comparative and statistical analysis of indicative values of innovation and technological development of the BRICS member countries. So, the systematic approach is reflected in the application of all elements of the innovation process (state, science, industry, etc.), which allows to identify trends in the technological development of the economies of the BRICS countries. Investigating problems of technological transfer in the countries of the BRICS, the authors analyse both statistical data, and the legislative base which is the cornerstone of formation of national innovative systems of member countries of BRICS. Methods of the comparative and statistical analysis of data are for this purpose applied.

\section{Results}

The Global Innovation Index (GII) is calculated annually by the Economist Intelligence Unit to assess the innovative development potential of the world. So, in 2020, the study covered 131 countries [11], which account for $99.4 \%$ of world GDP (Table 1). Russia, which was in 62 nd place in 2013, reached 47 th place in 2020.

Table 1. GII for the BRICS member countries, 2020.

\begin{tabular}{|c|c|c|c|c|c|c|}
\hline Country / Economy & $\begin{array}{ll}\text { Score } & (0- \\
100) & \\
\end{array}$ & Rank & Income & Rank & Region & Rank \\
\hline China & 53.28 & 14 & UM & 1 & SEAO & 4 \\
\hline Russian Federation & 35.63 & 47 & UM & 6 & EUR & 32 \\
\hline South Africa & 32.67 & 60 & $\mathrm{UM}$ & 14 & CSA & 2 \\
\hline India & 35.59 & 48 & LM & 3 & CSA & 1 \\
\hline Brazil & 31.94 & 62 & UM & 16 & CSA & 4 \\
\hline
\end{tabular}

World Bank Income Group Classification: LI - low income; LM - lower-middle income; UM upper-middle income; HI - high income. Regions are based on the United Nations Classification: EUR - Europe; NAC - Northern America; LCN - Latin America and Caribbean; CSA - Central and Southern Asia; NAWA - Northern Africa and Western Asia; SEAO - South East Asia, East Asia and Oceania [11] 
Each of the BRICS countries has gone its own way of innovative technological development, the formation of national innovation systems (NIS) and technology transfer systems, the main features of which we will consider. As note Edler\& Fagerberg [3], "There is a narrow perspective, considering invention only, and there is a broader, more holistic perspective, which emphasizes the importance of looking at the entire innovation cycle from the creation of novel ideas to their implementation and diffusion".

Brazil. The construction of the NIS of Brazil began in the 1900s. in the conditions of relatively closed micro- and macroeconomic processes, accompanying the state-proclaimed industrialization policy. In the 1940s, the creation of institutes implementing research, technological and industrial projects began. So, in 1947, the Center for Aerospace Research was created, which played a significant role in the development of Brazilian aircraft engineering. In 1951, the National Council of Scientific and Technological Research was formed, initially promoting atomic programs. The Council is now playing a significant role in funding public research, especially in university research centers. In 1953, the Development Bank of Brazil was established, which remains the main institution of longterm financing in Brazil. In 1964, two funds were established through the Bank to finance technological innovations - FUNTEC (finances training of personnel associated with the activities of university research centers) and FINAME (finances the development of mechanical engineering and the improvement of industrial equipment). In 1965, the National Agency for Financing Education and Research (FINEP) was formed, which until now is an important state enterprise for financing innovative processes.

In the 1970s there is a phased implementation of three Plans for the Development of Science and Technology. These plans were aimed at increasing the financial base of support for the development of technologies in the field of new energy sources, microelectronics and the aerospace industry, as well as at reorienting horizontal links between private and public entities.

In 1972, the Ministry of Industry and Trade of Brazil established the Secretariat of Industrial Technologies, whose activities are aimed at regulating the protection of intellectual property, coordinating research and technology programs, technological development of private and public companies, and technology transfer.

In 2006, the Government adopted the Act on Innovation, aimed at developing a technology transfer system from a research center to mass production. For its implementation, the Development Bank of Brazil creates a special program for financing entrepreneurs and enterprises wishing to increase $\mathrm{R} \& \mathrm{D}$ spending, introducing new productive business processes or new high-tech products.

At present, the Ministry of Science and Technology (established in 1985), which includes the National Council of Scientific and Technological Research and FINEP, is a key part of Brazil's national innovation system.

India. The NIS of India is a research centre with an extensive infrastructure, with both modern facilities for research and development in various fields (biotechnology, medicine, electronics, communication technologies and others) and interacting with enterprises to implement research results.

Having elected the US Massachusetts Institute of Technology in the early 1950s as the original model, India begins the creation of technological institutes that have received the status of technology parks (in New Delhi, Mumbai, Kampur and Madras), with the aim of forming centers of advanced knowledge and technology with the rapid introduction of the latter into production.

The first technological park - Softmare Technology Park of India (STPI) - was founded by the government of India in 1990 for development of the industry of software products and an entry into the world market. Priority problems of its functioning were: assistance and development of potential in export of software products; innovative activity; rendering full 
support to the companies releasing software products and the equipment for information technologies; rendering telecommunication and infrastructure services to the companies occupied with development and export of software products and which are a part of science and technology park [10].

STPI currently has 36 branches nationwide. Its headquarter is in Delhi. Technopark centers are located in Bangalore, Pune, Bhubaneshwar, Hyderabad, Gandinagar, Thiruvananthapuram, Chennai, Mohali, Jaipur, Navi Mumbai, Hubli and other cities. More than 7,500 companies specializing in export-only software development are members of STPI.

Technology parks in India have a number of benefits. So, they are completely exempt from import tax, and for five years - from paying domestic taxes and fees.

China. The formation of the modern NIS of China was preceded by the reforms of 197080 and the national development programs adopted on their basis. Approved in 1986, the state program for the development of science and high technologies "Program 863 " identified priority industries (microelectronics, informatics, space, fiber-optic technologies, genetic engineering and biotechnology, energy-saving technologies and medicine). The implementation of the Programme has been quite effective. So, literally in the 10 first years of its operation, over a thousand of the most important scientific and technical achievements were registered, of which 560 developments received worldwide recognition, 73 were awarded state prizes, 266 were patented abroad [8].

Two years later, China launched a new research and production program (Torch), which aimed at the commercialization and industrialization of knowledge-intensive technologies. In 1988, by a resolution of the State Council of China, the first technopark was established the Beijing High-Technology Industry Development Experimental Zone Zhongguancun (in 1999 Zhongguancun has become the "Zhongguancun Science \& Technology Zone" or Zpark).

The integration component in China has its own territorial organization. It is based on the division into the High technology and development zones (HTDZ), formed in the mid-1980s, which are scientific and technological parks.

In 2020, China had $168 \mathrm{HTDZ}$ at various levels, including 53 for strategic purposes (China Development Zones Association, 2020). Among Chinese HTDZ, one can distinguish zones located in the central regions (Beijing, Shenyang), as well as in the coastal regions (Shanghai, Hainan). During the existence of the Shenyan technopark zone, about 600 new types of high-tech products were developed and introduced into production.

China's state policy is aimed at fully supporting enterprises of new and high technologies, technology park structures, and the effective development of the country's economy, which focuses on its own scientific and technical potential. According to the national program adopted in 2006, the state authorities are obliged to allocate a certain share of their expenses for the products of only Chinese innovative companies, despite the profitability/disadvantage of such purchases. Under the new regulations, public authorities can only purchase foreign products if there is no alternative in China [8].

Republic of South Africa. In 2013, Bloomberg Rankings included the Republic of South Africa for the first time. According to the World Intellectual Property Organization published following the results of 2019 in the rating of the countries of the world by the number of patents of the Republic of South Africa rose to the 24th place, having overtaken Austria, Sweden, Switzerland and a number of other countries [12].

The Republic of South Africa is experiencing a steady increase in R \& D spending (so, the public expenditures grew from 300 million dollars in 1997 to 5,266 million dollars in 2020). Analyzing the structural component of innovation costs, we note that mainly funds are spent on innovations in industrial production and technology, scientific research of the 
Earth and outer space, in activities related to the use of computer technology and information technology.

The Republic of South Africa is currently striving to establish an effective national innovation system, create sustainable linkages between the participants in the innovation process and the technology transfer system being created. To achieve this goal, the South African Association for Scientific Research and Innovation Management (SARIMA) was founded in 2002. SARIMA has taken the lead in this process. This Association is funded by both the South African Government and various academic organizations, as well as philanthropists from the USA and Europe.

Russia. The technology transfer system that has developed at the moment in Russia is characterized by a number of features characteristic of the transition period. Thus, «an effectively developing economy is characterized by the predominance in the structure of imports of new knowledge-intensive technologies, and in the structure of exports - on the contrary, the marketing of mature technologies» [10].

According to the Federal State Statistic Service of Russia [4], in the structure of exports in technology trade, only scientific research was the predominant of all transaction objects. For other objects of transactions, the share of imports showed a significant excess over the share of exports (see tab. 2). In the system of transfer of advanced production technologies with foreign partners (see tab. 3), there is a noticeable significant excess of imports over exports as a whole [5], which corresponds to the preferential import of technologies that do not have a sufficient degree of novelty from the position of the global technology market. Thus, $86.6 \%$ of advanced technologies developed are new for Russia, of which only $13.4 \%$ are brand new in the global market.

Table 2. Trade in Technology with foreign countries by the subject of agreement, 2020

\begin{tabular}{|c|c|c|c|c|c|c|}
\hline \multirow{2}{*}{ Subject of agreement } & \multicolumn{3}{|c|}{ Exports } & \multicolumn{3}{|c|}{ Imports } \\
\hline & \begin{tabular}{|l|} 
Agree \\
ments
\end{tabular} & $\begin{array}{l}\text { Cost } \text { of subject } \\
\text { of agreement, } \\
\text { mln US dollars }\end{array}$ & $\begin{array}{l}\text { Receipts for } \\
\text { year, mln } \\
\text { US dollars }\end{array}$ & $\begin{array}{l}\text { Agree } \\
\text { ments }\end{array}$ & \begin{tabular}{|l|} 
Cost of subject \\
of agreement, \\
mln US dollars
\end{tabular} & $\begin{array}{l}\text { Payments for } \\
\text { year, mln US } \\
\text { dollars }\end{array}$ \\
\hline Total & 4196 & 66565 & 3520 & 5518 & 12323 & 4837 \\
\hline \multicolumn{7}{|l|}{$\begin{array}{l}\text { including by subject } \\
\text { of agreement: }\end{array}$} \\
\hline patent on invention & 8 & 2.4 & 1.4 & 34 & 89.0 & 4.6 \\
\hline $\begin{array}{l}\text { patent on selection } \\
\text { achievement }\end{array}$ & 1 & 0.0 & 0.0 & 19 & 1.3 & 0.8 \\
\hline $\begin{array}{l}\text { patent license } \\
\text { on invention }\end{array}$ & 163 & 141 & 34.0 & 277 & 742 & 220 \\
\hline utility model & 6 & 1.3 & 1.3 & 12 & 8.7 & 7.2 \\
\hline know-how & 75 & 22.7 & 4.7 & 235 & 955 & 486 \\
\hline trademark & 95 & 13.4 & 4.1 & 416 & 1017 & 580 \\
\hline industrial design & 5 & 1.6 & 0.1 & 22 & 4.1 & 4.1 \\
\hline engineering services & 1144 & 64302 & 2588 & 2382 & 7326 & 2824 \\
\hline $\begin{array}{ll}\text { research } \\
\text { development }\end{array} \quad$ and & 1142 & 1230 & 397 & 512 & 157 & 120 \\
\hline others & 1558 & 851 & 490 & 1628 & 2023 & 591 \\
\hline
\end{tabular}


Table 3. Advanced production technologies developed by groups, 2015-2019 (units).

\begin{tabular}{|l|l|l|l|l|}
\hline Advanced production technologies & Total number of & Category \\
\cline { 3 - 5 } & technologies & $\begin{array}{l}\text { New for } \\
\text { Russia }\end{array}$ & & Brand \\
new & & $\begin{array}{l}\text { Number } \\
\text { technologies using } \\
\text { patented inventions }\end{array}$ \\
\hline Total & & & & \\
\hline 2015 & 1398 & 1223 & 175 & 589 \\
\hline 2019 & 1620 & 1403 & 217 & 530 \\
\hline including: & & & & \\
\hline design and engineering & & & & \\
\hline 2015 & 359 & 323 & 36 & 145 \\
\hline 2019 & 456 & 403 & 53 & 168 \\
\hline production, processing and assembly & & & & \\
\hline 2015 & 548 & 471 & 77 & 247 \\
\hline 2019 & 510 & 447 & 63 & 173 \\
\hline $\begin{array}{l}\text { automated uploading lownloading } \\
\text { actions; materials and parts transporting }\end{array}$ & & & & \\
\hline 2015 & 12 & 10 & 2 & 6 \\
\hline 2019 & 29 & 25 & 4 & 10 \\
\hline $\begin{array}{l}\text { automated surveillance (monitoring) } \\
\text { devices }\end{array}$ & & & & \\
\hline 2015 & 117 & 82 & 35 & 53 \\
\hline 2019 & 159 & 98 & 61 & 88 \\
\hline communication and control & & & & \\
\hline 2015 & 232 & 218 & 14 & 92 \\
\hline 2019 & 316 & 295 & 21 & 55 \\
\hline production informational system & & & & \\
\hline 2015 & 84 & 78 & 6 & 33 \\
\hline 2019 & 81 & 73 & 8 & 18 \\
\hline $\begin{array}{l}\text { integrated control and monitoring } \\
\text { systems }\end{array}$ & & & & \\
\hline 2015 & 46 & 62 & 7 & 18 \\
\hline 2019 & 69 & & \\
\hline
\end{tabular}

The basis of the currently formed technology transfer system was laid in the USSR in the 1950s. The integration processes taking place then in the academic and university environment led to the interaction of scientific organizations with production, with sectoral ministries and departments. In the 1970s, inter-university complexes appeared in the country, uniting scientific teams of various universities in order to solve joint research and scientific and technical problems.

In the 1990s Russia is forming a number of new integrated scientific and educational structures (university complexes, scientific and educational and other centers). However, this is accompanied by a sharp reduction in the network of design and design organizations, experimental plants, scientific and technical services of enterprises (that is, structures designed to ensure the transfer of scientific results to the innovative sphere). Thus, until the early 2000 s, there was an increase in the number of research institutes through the creation of new or fragmentation of existing organizations. This was often not done by strengthening the research base of universities and enterprises (the basis of innovative systems in developed market economies), but by the formation of new legal entities.

Everything that happened led to institutional irregularities in the structure of science: if in 1992 there were 3437 independent scientific research institutes, the construction, design and exploration organizations, then in 2018 their number was reduced to 1848 organizations, and from them the number of the design and survey organizations was reduced by 24.8 times 
[5]. At the same time, there are noticeable trends towards an increase in the number of educational organizations and experienced enterprises.

The technological transfer system established in Russia was formed in the conditions of socio-economic transformation. In this regard, there is a need to create an effective mechanism for organizing innovative processes aimed at the interaction of all its participants - the state, production enterprises, institutes of science and education. The foreign experience we reviewed shows the need to create an appropriate innovative infrastructure, which includes: an innovative entrepreneurship-oriented legislative framework that guarantees the protection of intellectual property rights; scientific and educational centers, scientific and technological parks, technology transfer and commercialization centers and other specialized organizations that contribute to the transformation of promising scientific ideas into product and other innovations; financing R\&D through the business sector, development of a network of various funds, venture capital firms, small-scale enterprises, other elements of innovation infrastructure.

\section{Conclusions}

Although the theoretical basis of research on innovative processes is very significant, there are still many controversial and insufficiently studied issues, such as the formation of effective mechanisms and the choice of technological transfer tools, the dynamics of innovative and technological development of countries, the use of various institutional structures in the regulation of innovative processes, etc.

The formation of an organizational and economic mechanism focused on ensuring the process of obtaining, implementing and disseminating the results of scientific research and development with the involvement of all participants in the innovation process will contribute to increasing the efficiency of technology transfer. The formation of a system based on the integration of state institutions, the scientific and educational sphere and business in the BRICS member countries will contribute to the creation of competitive products, improving the status of countries in the global technology market.

\section{References}

1. R. Aoyama. J. of contemp. East Asia Studies, 5, 3 (2016)

2. China Development Zones Association (2020) www.cadz.org.cn/

3. J. Edler, J. Fagerberg. Oxford Review of Economic Policy, 33, 2 (2017)

4. Russian Statistical Yearbook (2020) https://rosstat.gov.ru/

5. Russia in numbers (2020) https://rosstat.gov.ru/

6. L. Shkvarya, O. Grigorenko, A. Strygin, V. Rusakovich, S. Shilina. Centralnaya Aziya i Kavkaz, 19, 119 (2016)

7. L. Shkvarya, H. Yu. Modern Global Economic System, 1209 (2021)

8. Yu. Solovieva, M. Chernyaev, A. Korenevskaya. J. of Appl. Econ. Sci., 12, 1473 (2017)

9. Yu.V. Solovieva. Analysis of Intern. Relations, 78 (2018)

10. Yu. Solovieva, Economic journal, 4, 85 (2015)

11. The Global Innovation Index (2020) www.wipo.int/

12. World Intellectual Property Indicators (2020) www.wipo.int/ 